\title{
AN ASSESSMENT OF THE CAROLINE CREEK FRESHWATER CRAYFISH RESERVE IN NORTHERN TASMANIA
}

\author{
by P. Horwitz and P. Hamr
}

(with one text-figure)

HORWIT/. P. \& HAMR, P., 1988 (31:x): An assessment of the Caroline Creek crayfish reserve in northern Tasmania. Pap. Proc. R. Soc. Tasm. 122(2): 69-72. https://doi.org/10.26749/rstpp.122.2.69

ISSN 008()-4703. Centre for Environmental Studies and Department of Zoology, University of Tasmania, G.P.O. Box 252C, Hobart, Australia 7001.

A preliminary investigation of the Caroline Creek freshwater crayfish reserve was conducted over a three day period in 1987. Data are presented to show that the population numbers of Astacopsis gouldi, for which the reserve was gazetied, are low and that large and mature animals were not found. The presence of numerous bait lines throughout the reserve shows that illegal fishing has occurred and is continuing, and suggests that management practices for the reserve have been inappropriate. The need for effective reserves for $A$. gouldi is discussed.

Key Words: freshwater crayfish, fishing reserve, northern Tasmania.

\section{INTRODUCTION}

The freshwater crayfish or lobster Astacopsis gouldi Clark is endemic to Tasmania, occurring in most river systems draining north into Bass Strait, and in Arthur River in northwestern Tasmania (Swain et al. 1982). Early records of the species given by Gould (1870) and Smith (1909) indicate that during the early part of European occupation, the species was plentiful in Tasmania. In particular, specimens of this species were noted to be extremely large, approaching $4-5 \mathrm{~kg}$ in weight and might therefore have been regarded as the largest freshwater crayfish in the world (see for instance Francois 1960). The large size of the crayfish makes fishing for the species a popular recreational pastime for inhabitants of northern Tasmania.

In partial response to this popularity, and in order "... to (study) the habitats of the crayfish ..." (Lynch 1969), the Tasmanian Government declared a fishing reserve at Caroline Creck near Latrobe in northern Tasmania (Inland Fisheries Regulations 1973), in which fishing is illegal.

In recent times, increased accessibility of remote populations has led to the realisation that fishing pressure on $A$. gouldi might be deleterious to the species. Indeed, this contributed to listing of the species as "vulnerable" by the International Union for the Conservation of Nature (I.U.C.N., Wells et al. 1983). "Vulnerable" was defined as the status of a species where "... if the causal factors continue to operate, then the species might become endangered in the future ...". Articles on the conservation of freshwater invertebrates in Tasmania since 1983 have recognised the listing but have tended to imply that the species is safer from endangerment than other "vulnerable" species since there are regulations for the number and size of freshwater crayfish to be taken, and the crayfish were reserved in Caroline Creek (Williams 1983, Michaelis 1985). Indeed, Fulton (1987) believed the species to be widespread and common, and that it should not be listed at all. Despite such confidence, many people who regularly fish for the species claim that both the range and maximum size of the species have declined.

A decision was made to undertake a preliminary investigation of the status of the population of $A$. gouldi at Caroline Creek. Since no assessment of the population had been made since the reserve was gazetted, it was considered that such an investigation might assist in the management of the reserve.

\section{METHODS}

\section{Site Description}

Caroline Creek is a tributary of the Mersey River, with relatively undisturbed upper reaches flowing into an area used for both forestry practices and agriculture in its lower reaches. The 
$3 \mathrm{~km}$ reserve occurs in the lower reaches, between the Latrobe-Railton road (Tasmap 8115: 497299) and Dawsons Siding road (Tasmap 8115: 506318). White posts mark both extremities of the reserve.

The reserve is composed of three distinct sections. From the downstream boundary, section 1 consists of approximately $300 \mathrm{~m}$ of creek surrounded by farmland, with banks dominated by exotic willow (Salix sp.) and blackwood (Acacia melanoxy(on). Section 2, the middle part, extends for $600 \mathrm{~m}$, and occurs in relatively undisturbed vegetation (dominated by Eucalyptus amygdalina, Melaleuca ericifolia and Leptospermum lanigerum with ferns and cutting grass Gahnia grandis). Section 3, approximately $2 \mathrm{~km}$ in length, occurs upstream and comprises most of the reserve. The creek flows through an exotic pine plantation (Pinus radiata) with some Eucalyptus amygdalina and Leptospermum lanigerum along the banks. The exotic blackberry (Rubus fructicosus) is a conspicuous component of the riparian vegetation in each section.

Sections 2 and 3 exhibit canopy vegetation over the creek to provide a high proportion of shading, and additional cover in the form of fallen $\operatorname{logs}$ in the creek, particularly in section 2. The habitat might thus be considered to be adequate for A. gouldi since these conditions are apparently preferred (Gould 1870, Lynch 1969, Forteath 1985). However, a lower proportion of shading and log cover was found in section 1 , corresponding to the occurrence of emergent aquatic plants such as Typha sp. Whilst it was not the intention of the study to examine the differences between the number of crayfish in each section, such categorisation of the reserve helps to understand the habitat suitability for crayfish.

Astacopsis gouldi is one of two decapod crustaceans known from the creek system. An undescribed species of Engaeus (Horwitz 1986) is found in burrows near the creek. Several species of freshwater fish are known to occur in the creek, namely the sandy (Pseudaphritis urvillii), eels (Anguilla sp.) and galaxiids (Galaxias maculatus) as well as introduced brown and rainbow trout (Salmo trutta and $S$. gairdneri respectively).

\section{Sampling Methods}

Caroline Creek was sampled between 30 November and 2 December 1987, during which time weather conditions appeared to be optimal for collecting $A$. gouldi (mostly fine, often overcast, cool to mild temperatures, with some light rain falling on the night of the second day). The temperature of the water was measured at $13.5^{\circ} \mathrm{C}$ on the last day of sampling.

Sampling consisted of placing tangle nets, drop nets and lines, baited with large pieces of fresh fish, at appropriate places (for instance, in deep pools and channels, at the entrance to large crayfish burrows and amongst log jams). A total of 55 sites were baited over the three-day period $(8$, 15 and 32 bait sites in sections 1, 2 and 3 respectively). Approximately one-third of the reserve was sampled each day, with bait in position for at least 3-4 hours during the middle of the day. Nets and some bait lines were left in position overnight. In addition, crayfish were collected downstream of bait sites when they were found beneath logs or rocks or walking on the creek bed.

The locations were noted of all crayfish captured in the reserve. Their size (carapace length, CPL, using vernier calipers to the nearest $0.1 \mathrm{~mm}$ ) and sex were also recorded. The reproductive condition of females was recorded by observing the setation of the gonopore (Turvey 1980, Morgan 1986) and the presence or absence of eggs. Notes on their external condition (presence of temnocephalanas, hardness and cleanliness of shell) were made and all individuals were given a distinctive mark.

In order to determine whether the reserve was being fished or not, the number and location of bait lines were recorded. They were then removed from the reserve.

\section{RESULTS}

Over the three-day period a total of 24 individuals of $A$. gouldi were captured, ranging from 38.6 to $126.6 \mathrm{~mm} \mathrm{CPL}$ (fig. 1). Four crayfish in the lower part of this size range were seen but could not be captured. No crayfish of legal size $(>130 \mathrm{~mm}$ CPL) were found and no reproductively active females were found. The largest individual came from section 1, 12 came from section 2, and 11 came from section 3 . Of the 24, 15 individuals were collected from baits and the remaining 9 were found under logs or rocks or walking along the stream bed. No marked animals were recaptured.

Seventeen crayfish were found bearing temnocephalans; of these the two largest crayfish bore a large species (resembling Temnocephala quadricornis) whilst the remainder bore the small species $T$. tasmanica. 


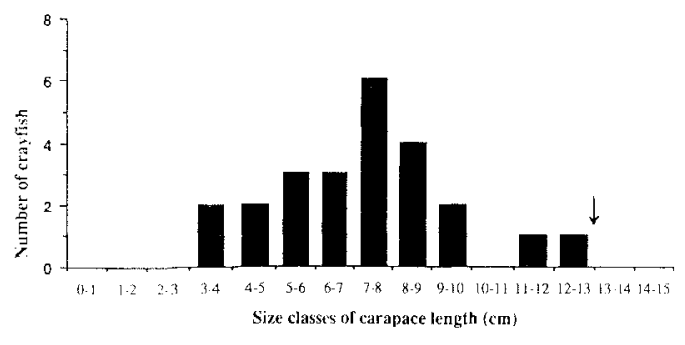

FIG. I - Size distribution of crayfish collected from Caroline Creek, presented in size classes of carapace length ( $C P L)$. The legal size limit for freshwater crayfish in Tasmania $(130 \mathrm{~mm})$ in indicated by an arrow.

Only one crayfish collected was not with a hard exoskeleton, indicating that the majority of specimens were not in an immediately pre- or postmoult condition.

A total of 29 old bait lines were found and removed from throughout the reserve (1, 9 and 19 lines found in sections 1,2 and 3 respectively).

\section{DISCUSSION}

The results suggest that there are few crayfish in the reserve. There are two sources of evidence for this assessment. Firstly, the low number of crayfish collected from what was considered to be suitable habitat. The numbers are very low when compared to other sites sampled in northern Tasmania where the sampling intensity has been equal or less, and where the numbers of crayfish collected were considerably larger. For instance, on the Inglis River, a section of $500 \mathrm{~m}$ of suitable habitat was baited at 29 sites over a threeday period in November and December 1985 and 46 animals were collected (Hamr, unpublished data). Secondly, the lack of females either in berry or in reproductive condition, suggests poor recruitment in the reserve itself, and in fact up to $400 \mathrm{~m}$ upstream of the reserve where attempts to collect individuals with baited lines met with no success. This assessment is made despite the fact that no recaptures were made. It is considered that there was insufficient time available in the sampling strategy to recapture the marked crayfish.

It is beyond the scope of this paper to determine if, and indeed how, the population has declined since being gazetted. However, some evidence was found, in the form of bait lines, to suggest that the reserve has been subjected to fishing pressure since, and possibly prior to, gazetting of the reserve. Lines ranged from being old and weathered to being recently placed with bait still attached. The absence of legally sized individuals of $A$. gould $i$ from our collections during this sampling period, supports this suggestion. Since taking of fish in this reserve is illegal (Regulation 8, Subregulation 1[1], Inland Fisheries Regulations 1973), our observations suggest that the management of the reserve has been inadequate.

Is is suggested that the current population does not warrant reserve status. This is ironical considering the hope of Lynch (1969) that "... information gained from observations in the study area (Caroline Creek) will provide a basis for the creation ... of larger reserves for the crayfish". However, reserve status should not be removed from the site without implementing complementary action such as gazetting of a new reserve and ensuring its adequate management.

Any new reserve should contain a demonstrably large and thriving population of $A$. gouldi in its natural range, and ideally should be undisturbed by forestry activity, agriculture, mining or the presence of trout and should not have suffered fishing pressure in the past. Some or all of these ideal attributes might be difficult to attain. It is of utmost importance to ensure that fishing is prevented in any new reserve otherwise fishing pressure on the crayfish may increase after gazetting due to the inadvertent advertising of a large population, particularly if accessible to nearby urbanisation. Easy access for road or offroad vehicles should be avoided to discourage illegal fishing. Without adequate protection, any reserved population of $A$. gouldi is at risk from recreational fishermen, as observed at Caroline Creek where reserve status has not prevented illegal exploitation. Given suitable management of the habitat and adequate policing, a new reserve or reserves for $A$. gould $i$ could be created that would contribute to conservation of the species and removal of the vulnerable status, conferred on the species by the I.U.C.N. (Wells et al. 1983).

\section{ACKNOWLEDGEMENTS}

Permits to fish for Astacopsis gouldi were provided by the Inland Fisheries Commission of Tasmania. Transport facilities were provided by the Centre for Environmental Studies. P. Hamr is in receipt of a University of Tasmania post-graduate 
scholarship. Wayne Fulton kindly confirmed the presence of freshwater fish species in Caroline Creek. Robert Sloane provided useful criticisms of an earlier draft of the manuscript.

\section{REFERENCES}

FORTEATH. N., 1985: Studies on the Tasmanian freshwater crayfish Astacopsis gouldi. Tasm. Inld Fish. Commn New'sl. 14: 5.

FRAN COIS, D.D., 1960: Freshwater crayfishes. Aust. Mus. Mag. 13: 217-221.

FULTON, W., 1987: Tasmania's endangered freshwater fauna. Tasm. Inld Fish. Commn Newsl. 16(1): 2-3.

GOULD, C., 1870: On the distribution and habits of the large freshwater crayfish (Astacus sp.) of the northern rivers of Tasmania. Proc. $R$. Soc. Tasm. (1870): 42-44.

HORWIT $L$, P., 1986: The systematics and biogeography of the freshwater crayfish genus Engaeus Erichson. Unpubl. Ph.D. thesis, Univ. Tasm.

LYNCH, D.D., 1969: Tasmanian giant freshwater crayfish Astacopsis gouldi Clark. Aust. Soc. Limnol. Bull. 2: 20-2I.
MICHAELIS, F.B., 1985: Rare or threatened species from inland waters of Tasmania, Australia. Rec Queen Vict. Mus. 87.

MORGAN, G.J., 1986: Freshwater crayfish of the genus Elastacus Clark (Decapoda, Parastatidae) from Victoria. Mem. Mus. Vict. 47: 1-57.

SMITH, G.W., 1909: A NATURALIST IN TASMANIA Oxford Clarendon Press, London.

SWAIN, R., RICHARDSON, A.M.M. \& HORTLE, M. 1982: Revision of the Tasmanian genus of freshwater crayfish Astacopsis Huxley (Decapoda: Parastacidae). Aust. I. Mur. Freshw Res. 33: 699-709.

TURVEY, S.P., 1980: Aspects of the biology of the freshwater crayfish Euastacus spinifer (Heller) (Decapoda: Parastacidae). Unpubl. M.Sc. thesis Univ. Sydney.

WELLS, S.M., PYLE, R.M. \& COLLINS, N.M., 1983. THE INTERNATIONAL UNION FOR THE CONSERVATION OF NATURE INVERTEBRATE RED DATA BOOK. IUCN, Gland Switzerland.

WILLIAMS, W.D., 1983: LIFE IN INLAND WATERS Blackwell Scientific Publications, Melbourne.

(accepted 20 May 1988) 